\title{
PEMUPUKAN NPK LODRIN 20-14-13 PRODUKSI CV SCORLEST PADA PEMBIBITAN KOPI (Coffea,sp) UNTUK MENGETAHUI TINGKAT EFISIENSI
}

\author{
M. Saeri dan F. N. Aziz
}

\begin{abstract}
The importance of NPK fertilizer for plants makes testing NPK fertilizer important to know the quality of fertilizer sold in the market. CV. Scorlest produces NPK fertilizers with doses of 20-1413 and labeled Lodrin. This fertilizer also needs to be tested its effectiveness on the resulting coffee seedlings. The use of NPK fertilizer is expected to affect the index of the readiness of seeds in coffee plants. Based on this research, this study aims to determine the level of effectiveness and efficiency of Lodrin fertilizer 20-14-13 on the growth of coffee seedlings. This experiment was conducted in the village of Kemiri, Jabung District, Malang Regency, conducted from August 2016 until December 2016. The experiment used a complete randomized block design with three replications. The clones used are BP 308 age 7 months. Based on the results of experiments conducted Lodrin Fertilizer 20-14-13 have the best quality seed index at a minimum dose of 3.5g per plant plus $0.75 \mathrm{~g}$ urea per plant technically this fertilizer passed as equal to standard fertilization and higher than the control. Lodrin fertilizer 20-14-13 gives $R$ / C ratio of 3.14 so that economically fertilizer is feasible for use in coffee cultivation business.
\end{abstract}

Keywords: Fertilizer, NPK, Coffee, Nurseries, Efficiency

\section{PENDAHULUAN}

Tanaman kopi di Indonesia hampir seluruhnya merupakan perkebunan kopi rakyat. Lokasi perkebunan kopi saat ini masih berdekatan dengan perkampungan dan di tempat-tempat yang relatif subur tanahnya. Hal ini menjadikan tanaman kopi rakyat hampir tidak pernah dipupuk. Kebiasaan ini masih berlangsung karena terdapatnya pasokan unsur-unsur hara dari reruntuhan dedaunan dan ranting dari tanaman kopi itu sendiri serta dari pohon pelindung. Hal ini menjadikan unsur hara yang dibutuhkan telah mencukupi. Kebiasaan ini bisa diperbaiki apabila tanaman kopi diharapkan memberikan produksi yang lebih baik dari sisi kuantitas maupun kualitasnya. Hal ini untuk meningkatkan produksi kopi nasional. Pemeliharaan secara optimal dan pemupukan secara teratur perlu dilakukan. Seperti tanaman perkebunan lainnya, tanaman kopi juga mulai dipupuk dari masa pembibitan sampai dengan di lapangan.

Pupuk organik mengandung unsur mikro dan makaro yang lengkap. Kebutuhan nutrisi lengkap pada tanaman sangat penting untuk aktivitas metabolisme. Seluruh aktivitas metabolisme tanaman akan sangat dipengaruhi oleh ketersediaan unsur hara dalam tanah (Prawinata et al., 1981). Pada pembibitan unsur phospor berperan pada pertumbuhan awal tanaman kopi yaitu untuk pembentukan akar. Kekurangan unsur fosfat menyebabkan menurunkan daya pertumbuhan pada pembibitan. Kekurangan phospor berkaitan erat dengan tanggap tanaman terhadap pemupukan $\mathrm{N}$ dan berasosiasi dengan meningkatnya kadar $\mathrm{Fe}$ hingga meracuni tanaman dan kekurangan $\mathrm{Zn}$, terutama pada tanah ber-pH rendah (Dobermann dan Fairhust, 2000). Unsur phosphor pada tanaman akan ditunjang oleh beberapa hal diantaranya adanya COrganik atau asam organik yang bersifat sebagai penyedia unsur P siap serap oleh akar. C-Organik dan asam-asam organik tersedia dalam pupuk organik.

Pada tanaman kopi penggunaan pupuk organik masih belum biasa dilakukan oleh petani karena petani masih merasa tanah yang mereka gunakan masih subur. Untuk mengatasi hal tersebut penggunaan pupuk pabrik 
yang tepat dosis diharapkan dapat meningkatkan pertumbuhan bibit kopi pada pertumbuhan awal sehingga mampu menjadi sumber bibit yang berkualitas dan siap tanam. Pupuk organik juga membawa unsur lain seperti $\mathrm{Ca}, \mathrm{Mn}, \mathrm{Cu}$, dan $\mathrm{Zn}$ sehingga melengkapi kebutuhan hara dan mengurangi masalah kemasaman tanah pada kopi (Wahyuningsih, 2012; Biswas dan Narayanasamy; 2006; Roesman, et al., 2015).

\section{Tujuan Penelitian}

Tujuan penelitian ini adalah untuk mengetahui tingkat efektivitas pupuk organik granul Organomax terhadap pertumbuhan bibit kopi Arabika.

\section{METODE PENELITIAN Waktu dan Tempat}

Percobaan ini dilakukan di Desa Kemiri Kec. Jabung, Kabupaten Malang, dimulai bulan Juli sampai dengan Desember 2016.

\section{Rancangan percobaan}

Penelitian menggunakan rancangan acak kelompok lengkap dengan sembilan perlakuan dan tiga ulangan. Satu petak terdiri dari 10 tanaman yang ditata pada jarak 70x70 $\mathrm{cm}$. Dosis standar untuk pupuk perlakuan adalah 1,5 g urea/tanaman $0,75 \mathrm{~g}$ $\mathrm{Kcl} /$ tanaman, dan $0,96 \mathrm{~g}$ SP-36 per tanaman dengan dosis pupuk organik 4 gr./tanaman (Wasdjar, 2002). Perlakuan pupuk disusun seperti pada Tabel 1. Pupuk organik yang digunakan adalah pupuk organik granul yang telah beredar di pasar yaitu Petroganik.

Tabel 1. Kombinasi dosis perlakuan pupuk Lodrin

\begin{tabular}{|c|c|c|c|c|c|c|}
\hline \multirow{2}{*}{$\begin{array}{l}\text { Kode } \\
\text { lapang }\end{array}$} & \multirow[b]{2}{*}{ Perlakuan } & \multicolumn{5}{|c|}{ Dosis (g/tanaman) } \\
\hline & & Urea & $\mathrm{KCl}$ & SP-36 & $\begin{array}{l}\text { Petro- } \\
\text { ganik }\end{array}$ & Lodrin \\
\hline $\mathbf{A}$ & Kontrol & 0 & 0 & 0 & 0 & 0 \\
\hline B & $\begin{array}{l}\text { 100\% NPK Rekomendasi+4 g } \\
\text { Petroganik }\end{array}$ & 1,5 & 0,75 & 0,96 & 4 & 0 \\
\hline $\mathbf{C}$ & $100 \%$ NPK Rekomendasi+2 g Lodrin & 1,5 & 0,75 & 0,96 & 0 & 2 \\
\hline D & 100\% NPK Rekomendasi+4 g Lodrin & 1,5 & 0,75 & 0,96 & 0 & 4 \\
\hline $\mathbf{E}$ & $100 \%$ NPK Rekomendasi+6 g Lodrin & 1,5 & 0,75 & 0,96 & 0 & 6 \\
\hline $\mathbf{F}$ & 50\% NPK Rekomendasi+2 g Lodrin & 0,75 & 0,375 & 0,48 & 0 & 2 \\
\hline G & 50\% NPK Rekomendasi+4 g Lodrin & 0,75 & 0,375 & 0,48 & 0 & 4 \\
\hline $\mathbf{H}$ & 50\% NPK Rekomendasi+6 g Lodrin & 0,75 & 0,375 & 0,48 & 0 & 6 \\
\hline $\mathbf{J}$ & 150\% NPK Rekomendasi+4 g Lodrin & 2,25 & 1,125 & 1,44 & 0 & 4 \\
\hline
\end{tabular}

Bahan-bahan yang digunakan meliputi: bibit kopi umur 7 bulan, alat pengolah tanah, sarana produksi (pupuk kandang, pupuk Urea, pupuk NPK, bibit/bibit kopi dan Pestisida). Pelaksanaan teknis di lapang adalah sebagai berikut.

\section{Teknis pelaksanaan di lapangan}

1. Persiapan bibit dan penanaman Media disiapkan dengan cara di cangkul gembur dan dicampur dengan perlakuan pupuk. Tanah dimasukkan pada polybag dan di tata berdasarkan lingkungannya.

2. Pemupukan dan Pemeliharaan

Pemupukan Sesuai dengan dosis perlakuan

3. Pengendalian OPT

Pestisida dilakukan berdasarkan pengendalian OPT secara terpadu dan intensif sehingga tanaman terhindar dari serangan hama dan penyakit.

4. Pengamatan dan destruksi sampel

Tanaman diamati berdasarkan parameter pengamatan dan sampel 
destruksi dilakukan untuk melihat bobot basah dan kering pada tajukakar.

\section{Penentuan lulus uji efektivitas}

Metode penilaian didasarkan pada panduan Peraturan Menteri Pertanian No 70/Permentan/SR140/10/2011 yaitu lulus uji secara teknis dan secara ekonomis. Ketentuan lulus uji adalah sebagai berikut:

a) Ketentuan lulus uji secara teknis Pupuk organik dinilai lulus uji efektivitas secara teknis apabila perlakuan pupuk secara statistik lebih baik dibandingkan dengan kontrol pada taraf nyata $5 \%$. Atau memiliki RAE $>100 \%$

b) Ketentuan lulus uji secara ekonomis Penggunaan pupuk organik dinilai lulus uji efektivitas secara ekonomis apabila analisis ekonomi usaha taninya menguntungkan dengan nilai $\mathrm{R} / \mathrm{C}>1$. Penilaian ekonomis dilakukan pada bibit kopi siap jual.

\section{Peubah yang diukur}

Peubah yang diamati meliputi pertumbuhan tanaman dan indeks mutu bibit yaitu:

1. Tinggi bibit

Tinggi bibit diukur dari pangkal batang sampai tunas tertinggi menggunakan penggaris. Satuan yang digunakan adalah sentimeter.

2. Diameter batang

Diameter batang diukur berdasarkan rata-rata diameter batang pada tiga titik menggunakan jangka sorong. Satuan yang digunakan adalah sentimeter.

3. Luas daun

Luas daun dihitung berdasarkan luas daun rata-rata per tanaman Satuan yang digunakan adalah sentimeter persegi. Luas daun menggunakan estimasi luas daun yang dilakukan Unigarro-Muñoz (2015) dengan estimasi sebagai berikut.

$$
E L A=0.99927 \times(L \times(-0.14757+0.60986 \times W))
$$

ELA: Luas daun

$\mathrm{L}$ : panjang daun

. Bobot kering akar

Bobot kering akar ditimbang dari berat tajuk setelah panen dan dikeringkan sampai stabil. Pengeringan dilakukan pada oven suhu $80^{\circ} \mathrm{C}$ selama tiga hari. Satuan yang digunakan adalah gram per tanaman.

5. Bobot kering tajuk

Bobot kering tajuk ditimbang dari berat tajuk setelah panen dan dikeringkan sampai stabil. Pengeringan dilakukan pada oven

$$
\text { I. }=\frac{B}{\frac{T}{D}+\frac{B}{B}}
$$

suhu $80^{\circ} \mathrm{C}$ selama tiga hari. Satuan yang digunakan adalah gram per tanaman.

6. Nisbah bobot tajuk/akar

Nisbah bobot tajuk/akar adalah rasio bobot kering tajuk dibandingkan bobot kering akar

7. Indeks Mutu Bibit

Indeks mutu bibit merupakan indikator kesiapan bibit untuk ditanam di lapang. Perhitungan didasarkan pada Dickson, et al. (1960) dengan rumus sebagai berikut
IMB : Indeks Mutu Bibit
D : diameter batang
BK : Berat kering
BKT : Berat Kering Tajuk
$\mathrm{T}$ : Tinggi Tanaman
BKA : Berat Kering Akar 


\section{HASIL DAN PEMBAHASAN}

\section{Kondisi umum penelitian}

Penelitian dilakukan di Desa

Kemiri Kecamatan Jabung Kabupaten Malang. Tanaman mulai di tanam pada polibag baru beserta media tanam pada tanggal 18 Agustus 2016. Suhu di lokasi penelitian menunjukkan suhu yang relatif stabil dengan range harian cukup tinggi. Suhu tertinggi pada suhu $35^{\circ} \mathrm{C}$ sedangkan suhu terendah $20^{\circ} \mathrm{C}$ (Gambar 1). Intensitas hujan di lokasi juga cukup tinggi (Gambar 2).

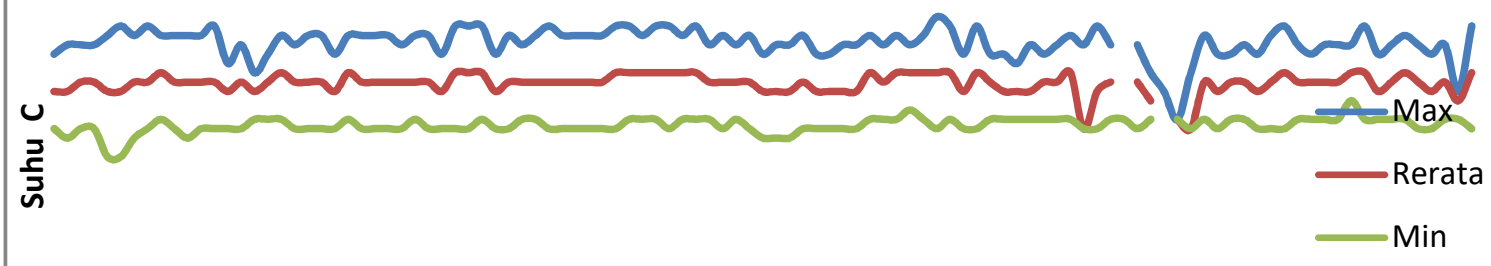

Gambar 1. Suhu harian di Lokasi Penelitian (Stasiun Abdul Rahman Saleh)

Kondisi iklim seperti ini menyebabkan resiko serangan OPT yang cukup tinggi. di lapang banyak ditemukan aphid sehingga pengendalian hama ini intensif dilakukan. Pupuk organik granul Organomax memiliki kandungan $\mathrm{C}$ Organik $17,44 \%$ dengan $\mathrm{C} / \mathrm{N} 17,10 \%$. Pupuk organik granul Organomax dilengkapi dengan mikroba penambat $\mathrm{N}$ dan Pelarut $\mathrm{K}$ (Permentan No 206 tahun 2016).

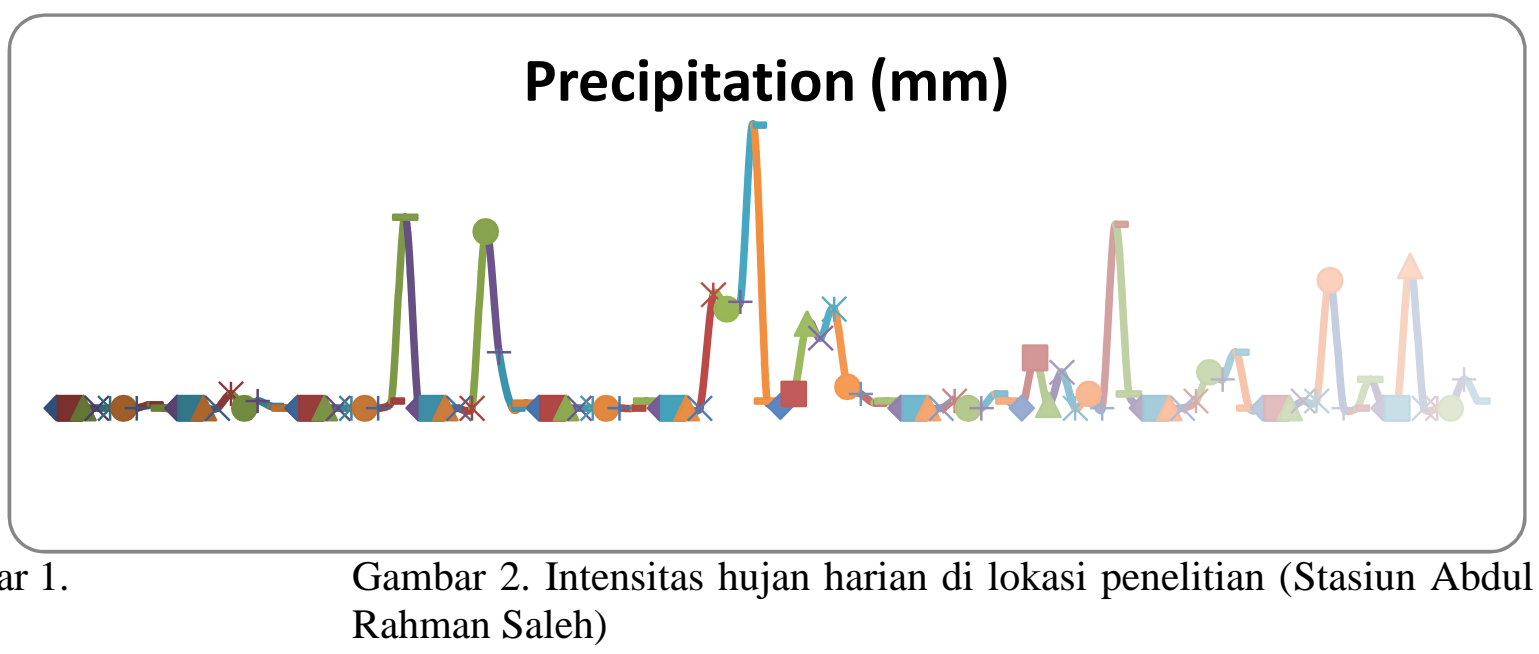

Gambar 2.

\section{Komponen Pertumbuhan}

Pertumbuhan tinggi bibit kopi pada sembilan perlakuan yang dierikan menunjukkan pengaruh pada parametertinggi tanaman mulai dipengaruhi oleh perlakuan yang dilakukan pada minggu ke 3 (21 hari setelah tanam) (Tabel 2 dan Tabel 3). Pertumbuhan bibit kopi tidak dipengaruhi adanya pupuk organik granul Organomax maupun pupuk kontrol pada umur 0-14 hari setelah aplikasi pemupukandapat disebabkan karena pengaruh pupuk organik yang diberikan baru terlihat 
setelah umur 21 hari. Pupuk organik mengandung asam organik yang dapat meningkatkan penyerapan hara karena meningkatkan daya jerap akar terhadap unsur hara.

Tinggi tanaman merupakan variabel yang menunjukkan pertumbuhan tanaman. Pada pertumbuhan tinggi tanaman bibit kopi yang diberikan pupuk granul yang berasal dari Organomax maupun Petroganik memberikan pertumbuhan yang lebih baik dibandingkan dengan perlakuan kontrol.

Diameter batang tidak dipengaruhi oleh perlakuan pupuk yang diberikan. Pada kontrol dan pemberian perlakuan menunjukkan diameter yang sama dengan rerata $0,7271 \mathrm{~cm}$. Hal ini
Untuk Mengetahui Tingkat Efisiensi

dapat dikarenakan pertumbuhan bibit kopi pada penelitian sudah mengalami pertumbuhan secara liniar sehingga pemberian pemupukan dapat tidak berpengaruh pada diameter batang. Luas daun total juga tidak dipengaruhi oleh perlakuan pupuk organik granul. Luas daun total pada perlakuan adalah 2031,60 $\mathrm{cm}^{2}$ dengan CV 9,38\% (Tabel 4). Tidak dipengaruhinya luas daun juga dapat menjadi penyebab tidak ada pengaruhnya terhadap diameter batang. Hal ini karena luasan daun menunjukkan banyaknya asimilat yang di salurkan ke batang. Tidak adanya perbedaan luas daun menyebabkan tanaman tidak melakukan pertumbuhan batang secara maksimal

Tabel 2. Pertumbuhan bibit kopi pada umur 0 sampai 35 hari setelah perlakuan.

\begin{tabular}{|c|c|c|c|c|c|c|c|c|c|}
\hline \multirow[b]{2}{*}{ Perlakuan } & \multicolumn{9}{|c|}{ Umur tanaman (hari setelah perlakuan) } \\
\hline & 0 & 7 & 14 & 21 & & 28 & & 35 & \\
\hline Uji F & tn & tn & tn & $*$ & & $*$ & & $*$ & \\
\hline Kontrol & 45.03 & 46.7 & 48.23 & 48.37 & $\mathrm{~b}$ & 49.03 & $\mathrm{~b}$ & 49.87 & $\mathrm{~b}$ \\
\hline 100\% NPK Rekomendasi+4 g Petroganik & 44.83 & 46.7 & 48.5 & 50.83 & $\mathrm{a}$ & 51.6 & a & 52.47 & a \\
\hline $100 \%$ NPK Rekomendasi+2 g Lodrin & 45.17 & 47.17 & 49.3 & 50.83 & a & 51.6 & a & 52.5 & a \\
\hline 100\% NPK Rekomendasi+4 g Lodrin & 45.3 & 47.37 & 49.33 & 51.03 & $\mathrm{a}$ & 51.77 & $\mathrm{a}$ & 52.63 & a \\
\hline 100\% NPK Rekomendasi+6 g Lodrin & 44.7 & 46.8 & 48.63 & 50.67 & a & 51.43 & a & 52.4 & a \\
\hline $50 \%$ NPK Rekomendasi+2 g Lodrin & 44.9 & 47.1 & 49.27 & 50.8 & $\mathrm{a}$ & 51.73 & $\mathrm{a}$ & 52.5 & a \\
\hline $50 \%$ NPK Rekomendasi+4 g Lodrin & 44.97 & 47 & 49.27 & 50.8 & $\mathrm{a}$ & 51.67 & a & 52.47 & a \\
\hline $50 \%$ NPK Rekomendasi+6 g Lodrin & 45.2 & 47.13 & 49.27 & 50.83 & a & 51.6 & a & 52.37 & a \\
\hline 150\% NPK Rekomendasi+4 g Lodrin & 44.97 & 46.97 & 48.93 & 50.77 & $\mathrm{a}$ & 51.4 & a & 52.6 & $\mathrm{a}$ \\
\hline
\end{tabular}

Keterangan: angka yang diikuti huruf yang sama tidak berbeda nyata pada BNJ 5\%

Pertumbuhan bibit kopi umur 42- 80 hari setelah perlakuan (lanjutan Tabel 2).

\begin{tabular}{|c|c|c|c|c|c|c|c|c|c|c|}
\hline \multirow[b]{2}{*}{ Perlakuan } & \multicolumn{10}{|c|}{ Umur tanaman (hari setelah perlakuan) } \\
\hline & 42 & & 49 & & 56 & & 63 & & 70 & \\
\hline Uji F & $*$ & & $*$ & & $*$ & & $*$ & & $*$ & \\
\hline Kontrol & 50.73 & $\mathrm{~b}$ & 51.77 & $\mathrm{~b}$ & 52.53 & $\mathrm{~b}$ & 53.6 & $\mathrm{~b}$ & 55.53 & $\mathrm{~b}$ \\
\hline 100\% NPK Rekomendasi+4 g Petroganik & 53.43 & $\mathrm{a}$ & 54.2 & a & 55.2 & $\mathrm{a}$ & 56.13 & a & 58.03 & $\mathrm{a}$ \\
\hline $100 \%$ NPK Rekomendasi+2 g organomax & 53.4 & $\mathrm{a}$ & 54.53 & a & 55.27 & a & 55.93 & a & 58.03 & a \\
\hline $100 \%$ NPK Rekomendasi+4 g organomax & 53.43 & $\mathrm{a}$ & 54.57 & a & 55.33 & $\mathrm{a}$ & 56.13 & a & 58.13 & $a$ \\
\hline $100 \%$ NPK Rekomendasi+6 g organomax & 53.5 & $\mathrm{a}$ & 54.13 & a & 55.03 & a & 55.87 & a & 57.9 & $\mathrm{a}$ \\
\hline $50 \%$ NPK Rekomendasi+2 g organomax & 53.33 & $\mathrm{a}$ & 54.37 & a & 55.33 & a & 56 & a & 58.07 & $\mathrm{a}$ \\
\hline $50 \%$ NPK Rekomendasi+4 g organomax & 53.53 & $\mathrm{a}$ & 54.33 & a & 55.3 & a & 56 & $\mathrm{a}$ & 58 & $\mathrm{a}$ \\
\hline $50 \%$ NPK Rekomendasi+6 g organomax & 53.3 & $\mathrm{a}$ & 54.27 & $\mathrm{a}$ & 55.17 & a & 55.93 & $\mathrm{a}$ & 58 & $\mathrm{a}$ \\
\hline $150 \%$ NPK Rekomendasi+4 g organomax & 53.37 & $\mathrm{a}$ & 54.17 & $\mathrm{a}$ & 55.23 & $\mathrm{a}$ & 55.9 & $\mathrm{a}$ & 57.9 & $\mathrm{a}$ \\
\hline
\end{tabular}

Keterangan: angka yang diikuti huruf yang sama tidak berbeda nyata pada BNJ 5\% 
Tabel 3. Diameter batang dan luas daun pada tanaman kopi

\begin{tabular}{lrr}
\hline \multicolumn{1}{c}{ Variabel } & Rerata & CV $(\%)$ \\
\hline Diameter batang $(\mathrm{cm})$ & 0,7271 & 10,70 \\
Luas Daun & 2031,60 & 9,38 \\
\hline
\end{tabular}

\section{Indeks mutu bibit}

Indeks mutu bibit dipengaruhi oleh hasil asimilasi yang digunakan selama penelitian yang berlangsung. Indeks mutu bibit dipengaruhi oleh bobot keringtotal, nisbah tajuk akar,tinggi tanaman dan diameter daun. Diameter tanaman dan nisbah tajuk akar adalah parameter indeks mutu bibit yang tidak dipengaruhi oleh perlakuan pemupukan yang diberikan.
Bobot kering akar dan bobot kering tajuk memiliki trend yang sama dimana kontrol lebih rendah diabndingkan dengan perlakuan pemberian pupuk granul baik dari Organomax maupun produk kompetitor dari Petroganik. Hal ini menyebabkan perlakuan pupuk granul dan kontrol tidak mempengaruhi nisbah tajuk akar.

Tabel 4. Bobot kering akar, bobot kering tajuk dan nisbah tajuk akar pada sembilan perlakuan pupuk.

\begin{tabular}{|c|c|c|c|c|c|}
\hline Perlakuan & Bobot kering akar & & Bobot kering tajuk & & Nisbah tajuk akar \\
\hline Uji F & $*$ & & * & & tn \\
\hline Kontrol & 22 & $\mathrm{~b}$ & 12.67 & $\mathrm{~b}$ & 0.5751 \\
\hline 100\% NPK Rekomendasi+4 g Petroganik & 28.33 & a & 19 & $\mathrm{a}$ & 0.6704 \\
\hline 100\% NPK Rekomendasi+2 g Lodrin & 29.33 & a & 20.33 & $\mathrm{a}$ & 0.6927 \\
\hline 100\% NPK Rekomendasi+4 g Lodrin & 29.67 & a & 19 & $\mathrm{a}$ & 0.6396 \\
\hline 100\% NPK Rekomendasi+6 g Lodrin & 29.33 & a & 20.33 & $\mathrm{a}$ & 0.6931 \\
\hline $50 \%$ NPK Rekomendasi+2 g Lodrin & 30 & a & 19.33 & $\mathrm{a}$ & 0.6445 \\
\hline $50 \%$ NPK Rekomendasi+4 g Lodrin & 30 & $\mathrm{a}$ & 19.33 & $\mathrm{a}$ & 0.6444 \\
\hline $50 \%$ NPK Rekomendasi+6 g Lodrin & 29.33 & $\mathrm{a}$ & 18 & $\mathrm{a}$ & 0.6138 \\
\hline 150\% NPK Rekomendasi+4 g Lodrin & 28.67 & a & 17.67 & $\mathrm{a}$ & 0.6183 \\
\hline
\end{tabular}

Keterangan: *: nyata pada Uji F 5\%; tn: tidak nyata pada uji F 5\%; angka yang diikuti huruf yang sama tidak berbeda nyata pada BNJ 5\%

Nisbah tajuk akar menunjukkan besarnya kesiapan akar bibit kopi. Semakin besar bobot kering akar akan meningkatkan kesiapan bibit untuk dilakukan pindah tanam (Dickson et al., 1960). Nisbah yang tidak berbeda menunjukkan kesiapan akar bibit kopi pada seluruh perlakuan sama.

Rasio tinggi tanaman dan diameter batang merupakan indikator vigor tanaman. Semakin rendah nilai rasio tersebut akan menurunkan vigor tanaman Berdasarkan Tabel 4 tinggi kontrol lebih rendah dibandingkan dengan tinggi tanaman perlakuan pemupukan pupuk granul namun diameter batang tanaman pada seluruh perlakuan sama. Meskipun diameter batang tanaman sama untuk seluruh perlakuan ternyata nisbah tinggi tanaman dan diameter tidak berbeda nyata. Hal ini menunjukkan bahwa vigor tanaman pada seluruh pemupukan sama. Tidak berbedanya rasio tinggi tanaman dan rasio pucuk akar mengakibatkan faktor utama penentu indeks mutu bibit adalah bobot kering tanaman. 
Tabel 5. Tinggi tanaman, diameter, dan nisbah tinggi tanaman diameter pada sembilan perlakuan pupuk.

\begin{tabular}{lcccrr}
\hline \multicolumn{1}{c}{ Perlakuan } & $\begin{array}{c}\text { Tinggi } \\
\text { tanaman }(\mathrm{cm})\end{array}$ & Diameter $(\mathrm{cm})$ & Nisbah & \\
\hline Uji F & $*$ & & tn & tn \\
Kontrol & 55.53 & $\mathrm{~b}$ & 0.5884 & 82.74 \\
100\% NPK Rekomendasi+4 g Petroganik & 58.03 & $\mathrm{a}$ & 0.7576 & 86.09 \\
100\% NPK Rekomendasi+2 g Lodrin & 58.03 & $\mathrm{a}$ & 0.7105 & 91.79 \\
100\% NPK Rekomendasi+4 g Lodrin & 58.13 & $\mathrm{a}$ & 0.7575 & 76.84 \\
100\% NPK Rekomendasi+6 g Lodrin & 57.9 & $\mathrm{a}$ & 0.7651 & 91.21 \\
50\% NPK Rekomendasi+2 g Lodrin & 58.07 & $\mathrm{a}$ & 0.7723 & 89.46 \\
50\% NPK Rekomendasi+4 g Lodrin & 58 & $\mathrm{a}$ & 0.6996 & 86.16 \\
50\% NPK Rekomendasi+6 g Lodrin & 58 & $\mathrm{a}$ & 0.7916 & 76.92 \\
150\% NPK Rekomendasi+4 g Lodrin & 57.9 & $\mathrm{a}$ & 0.7011 & 91.67 \\
\hline Kerangan
\end{tabular}

Keterangan: *: nyata pada Uji F 5\%; tn: tidak nyata pada uji $\mathrm{F} 5 \%$; angka yang diikuti huruf yang sama tidak berbeda nyata pada BNJ $5 \%$

Bobot kering tanaman memiliki trend yang sama dengan bobot akar dan bobot tajuk. Hal ini menyebabkan bobot kering tanaman pada kontrol lebih rendah dibandingkan dengan bobot kering tanaman pada perlakuan pupuk granul. Pengaruh dosis dan jenis pupuk granul yang diberikan tidak ada pada bobot kering tanaman. Hal tersebut menjadikan indeks mutu pada seluruh pemupukan pupuk organik granul baik Petroganik maupun Organomax sama. Pemupukan organomax dengan pemupukan NPK lebih rendah menghasilkan indeks mutu bibit yang sama. Hal ini dapat menjadi efisiensi secara ekonomi.

Tabel 6. Bobot kering tanaman dan indeks mutu bibit pada sembilan perlakuan pupuk

\begin{tabular}{lrrrr}
\hline Perlakuan & Bobot kering tanaman $(\mathrm{g})$ & \multicolumn{2}{c}{ Indeks Mutu Bibit } \\
\hline Kontrol & 34.67 & $\mathrm{~b}$ & 0.3641 & $\mathrm{~b}$ \\
$100 \%$ NPK Rekomendasi+4 g Petroganik & 47.33 & $\mathrm{a}$ & 0.6125 & $\mathrm{a}$ \\
$100 \%$ NPK Rekomendasi+2 g Lodrin & 49.67 & $\mathrm{a}$ & 0.6048 & $\mathrm{a}$ \\
$100 \%$ NPK Rekomendasi+4 g Lodrin & 48.67 & $\mathrm{a}$ & 0.6283 & $\mathrm{a}$ \\
$100 \%$ NPK Rekomendasi+6 g Lodrin & 49.67 & $\mathrm{a}$ & 0.65 & $\mathrm{a}$ \\
$50 \%$ NPK Rekomendasi+2 g Lodrin & 49.33 & $\mathrm{a}$ & 0.6513 & $\mathrm{a}$ \\
$50 \%$ NPK Rekomendasi+4 g Lodrin & 49.33 & $\mathrm{a}$ & 0.5889 & $\mathrm{a}$ \\
$50 \%$ NPK Rekomendasi+6 g Lodrin & 47.33 & $\mathrm{a}$ & 0.6403 & $\mathrm{a}$ \\
$150 \%$ NPK Rekomendasi+4 g Lodrin & 46.33 & $\mathrm{a}$ & 0.5572 & $\mathrm{ab}$ \\
\hline
\end{tabular}

Keterangan: *: nyata pada Uji F 5\%; tn: tidak nyata pada uji F 5\%; angka yang diikuti huruf yang sama tidak berbeda nyata pada BNJ 5\%

Pupuk organik granul organomax secara teknis melebihi kontrol berdasarkan indeks mutu bibit dan sama dengan pupuk standar. Hal ini menunjukkan bahwa pupuk granul Organomax lulus secara teknis.

\section{Analisis Usaha Ekonomi}

berbagai perlakuan pemupukan ditunjukkan padaTabel 7 dan Tabel 8 . Biaya pupuk paling rendah adalah perlakuan F (50\% NPK Rekomendasi+2 g organomax). Karena secara agronomis pupuk ini sama dengan perlakuan lain namun memberikan pengaruh lebih baik dibandingkan dengan kontrol maka kombinasi perlakuan ini lebih direkomendasikan karena lebih ekonomis. 
Tabel 7. Analisis finansial usahatani bibit kopi dengan pemupukan rekomendasi dan $0,75 \mathrm{~g}$ urea $+3,5 \mathrm{~g}$ Lodrin.

\begin{tabular}{|c|c|c|c|c|c|}
\hline Uraian & Jumlah & Satuan & Biaya (Rp) & Kontrol & $\begin{array}{l}50 \% \text { NPK rekomendasi }+2 \mathrm{~g} \\
\text { Lodrin }\end{array}$ \\
\hline \multicolumn{6}{|l|}{ Biaya Saprodi: } \\
\hline Klon Stek & 30,000 & btg & 500 & 15.000 .000 & 15.000 .000 \\
\hline $\mathrm{ZPT}$ & 100 & btl & 15.000 & 1.500 .000 & 1.500 .000 \\
\hline Polibag & 30,000 & $\mathrm{~kg}$ & 400 & 12.000 .000 & 12.000 .000 \\
\hline \multicolumn{6}{|l|}{ Pupuk } \\
\hline Urea & 22.5 & $\mathrm{~kg}$ & 2.000 & & 45000 \\
\hline SP36 & 11.25 & $\mathrm{~kg}$ & 1.800 & & 20250 \\
\hline $\mathrm{KCl}$ & 14.4 & $\mathrm{~kg}$ & 10.000 & & 144000 \\
\hline Organomax & 60 & & 1.850 & & 111.000 \\
\hline \multicolumn{6}{|l|}{ Pestisida } \\
\hline Insektisida & 1 & paket & 500.000 & 500.000 & 500.000 \\
\hline Fungisida & 1 & paket & 500.000 & 500.000 & 500.000 \\
\hline \multicolumn{6}{|c|}{ Beaya Tenaga Kerja: } \\
\hline Penanaman & 30 & HOK & 25.000 & 750.000 & 750.000 \\
\hline Pembuatan media & 10 & HOK & 25.000 & 250.000 & 250.000 \\
\hline Pengairan & 1 & Musim & 1.200 .000 & 1.200 .000 & 1.200 .000 \\
\hline Penyiangan & 30 & HOK & 25.000 & 750.000 & 750.000 \\
\hline PHT & 10 & HOK & 25.000 & 250.000 & 250.000 \\
\hline \multicolumn{6}{|l|}{ Biaya lain-Lain } \\
\hline Sewa Lahan & \multirow{2}{*}{\multicolumn{2}{|c|}{1 ha }} & 10.000 .000 & 10.000 .000 & 10.000 .000 \\
\hline Total Biaya & & & & 42.700 .000 & 43.020 .250 \\
\hline Produksi(perha) & \multirow{3}{*}{\multicolumn{2}{|c|}{ bibit }} & & 30.000 & 30.000 \\
\hline Nilai Produksi & & & & 135.000 .000 & 135.000 .000 \\
\hline Pendapatan & & & & 92.300 .000 & 91.979 .750 \\
\hline R/C Ratio & & & & 3,16 & 3,14 \\
\hline
\end{tabular}

Keterangan : Harga Pupuk organik granul Organomax Rp 1.850; Urea = Rp 1.800; SP-36= Rp 2.000; KCl= Rp 10.000

Kondisi di lapang perlakuan kontrol digunakan paling banyak oleh para pedagang bibit. $\mathrm{R} / \mathrm{C}$ ratio pupuk perlakuan $50 \%$ NPK rekomendasi ditambah dengan $2 \mathrm{~g}$ organomax tidak lebih tinggi dari kontrol namun memiliki $\mathrm{R} / \mathrm{C}$ ratio lebih dari 1 (Tabel 3). Penggunaan organomax dengan dosis $2 \mathrm{~g}$ yang dikombinasikan 50\% NPK rekomendasi memberikan $\mathrm{R} / \mathrm{C}$ Ratio sebesar 3,14 yang berarti setiap $\mathrm{Rp} 1$ yang dikeluarkan dalam produksi bibit kopi akan menghasilkan keuntungan sebesar Rp 3,14. Hal ini menunjukkan bahwa pupuk organik granul Organomax layak secara ekonomis untuk digunakan.

Tabel 8. Rekapitulasi Biaya pupuk setiap perlakuan

\begin{tabular}{clr}
\hline Kode & \multicolumn{1}{c}{ Perlakuan } & Biaya pupuk \\
\hline A & Kontrol & - \\
B & 100\% NPK Rekomendasi+4 g Petroganik & 474.000 \\
C & $100 \%$ NPK Rekomendasi+2 g Lodrin & 525.000 \\
D & 100\% NPK Rekomendasi+4 g Lodrin & 636.000 \\
E & 100\% NPK Rekomendasi+6 g Lodrin & 747.000 \\
F & 50\% NPK Rekomendasi+2 g Lodrin & 318.000 \\
G & 50\% NPK Rekomendasi+4 g Lodrin & 429.000 \\
H & 50\% NPK Rekomendasi+6 g Lodrin & 540.000 \\
J & 50\% NPK Rekomendasi+4 g Lodrin & 843.000 \\
\hline
\end{tabular}

Keterangan : Harga Pupuk organik granul Organomax Rp 1.850; Urea = Rp 1.800; SP-36= Rp 2.000; KCl= Rp 10.000 


\section{KESIMPULAN DAN SARAN}

\section{Kesimpulan}

Pupuk organik granul Organomax efektif diberikan pada bibit tanaman kopi dengan dosis 2 g per tanaman untuk meningkatkan indeks mutu bibit yang lebih baik dibandingkan dengan kontrol dan setara dengan perlakuan standar dengan produk kompetitornya.Pupuk organik granul Organomax dapat memberikan $\mathrm{R} / \mathrm{C}$ ratio sebesar 3,14 sehingga secara ekonomi pupuk ini efektif untuk digunakan dalam usaha budidaya tanaman kopi

Saran

Secara teknis pupuk organik granul Organomax tidak memiliki pengaruhsama dibandingkan produk kompetitornya(Petroganik) sehingga dapat menjadi pupuk alternatif.

\section{DAFTAR PUSTAKA}

Al Jabri, M. 2007. Perkembangan uji tanah dan strategi program uji tanah masa depan di Indonesia. J. Litbang Pertanian, 26, 54-66.

Amalia, S. N., \& Dewi, M. 2011. Nilai indeks glikemik beberapa jenis pengolahan kopi (Zea mays saccharata Sturt). Jurnal Gizi dan Pangan, 6(1), 36.

Biswas, D. R., \& Narayanasamy, G. 2006. Rock phosphate enriched compost: an approach to improve lowgrade Indian rock phosphate.Bioresource Technology, 97(18), 22432251.

Dickson, Alexander, Albert L. Leaf, and John F. Hosner. 1960.
"Quality appraisal of white spruce and white pine seedling stock in nurseries." The Forestry Chronicle 36, no. 1: 10-13.

Dobermann, A. and T. Fairhurst. 2000. Nutrient disorders and nutrient management. IRRI and Potash \& PPI /PPIC. Manila, Philipina.

Kementerian Pertanian. 2015. Kalender Tanam April-September 2015 Kota Batu. Kementerian Pertanian. 25 pp

Marvelita, A., Darmanti, S., \& Parman, S. 2006. Produksi tanaman kopi (Zea mays 1. Saccharata) yang diperlakukan dengan kompos kascing dengan dosis yang berbeda. Jurnal Anatomi Fisiologi, 14(2).

Made, U. 2012. Respons berbagai populasi tanaman kopi (Zea mays saccharata Sturt.) terhadap pemberian pupuk urea. Agroland, 17(2).

Matanubun, H., Radjagukguk, B., \& Rusmarkam, A. 1988. Kajian pengaruh peningkatan $\mathrm{pH}$ tanah Podsolik merah-kuning atas pengambilan fosfor dari batuan fosfat oleh kopigogo (Oryza sativa L.) $=$ A Study on the Effect of Increasing $\mathrm{pH}$ of Red-Yellow Podzolicby Upland Rice (Oryza sa. Berkala Penelitian Pasca Sarjana, 1(1988).

Prawinata, W S Harran dan P Tjondronegoro, 1981. Dasar 
fisiologi tumbuhan (II). Dep. Botani Fak. Pertanian, IPB, Bogor.

Rahmi, A. 2007. Pengaruh Konsentrasi dan Waktu Penyemprotan Pupuk Organik Cair Super ACI terhadap Pertumbuhan bibit kopi.Agritrop, 26(3).

Rosman, R, Setyono dan H Suhaeni. 2015. Pengaruh naungan dan pupuk fosfor terhadap pertumbuhan dan produksi nilam (Pogostemon cablin Benth.).

Suriadikarta, D A, D Setyorini, W Hartatik. 2004. Uji Mutu dan Efektifitas Pupuk Alternatif Anorganik. Balai Penelitian Tanah, Bogor.50 hal

Suyamto, 2003. Pemetaan Kesuburan Tanah Lahan Sawah dan Sistem Produksi Kopidi Jawa Timur 2001 dan 2003. Dinas Pertanian Propinsi Jawa Timur, Balai Pengkajian Teknologi Pertanian Jawa Timur

Tuherkih, E., \& Sipahutar, I. A. 2008. Pengaruh pupuk NPK majemuk (16: 16: 15) terhadap pertumbuhan dan hasil jagung (Zea mays L) di tanah inceptisols.Bogor Balai Penelitian Tanah, 10-11.

Unigarro-Muñoz, Carlos Andrés, Juan David HernándezArredondo, Esther Cecilia Montoya-Restrepo, Ruben Darío Medina-Rivera, Lizardo Norbey IbarraRuales, Claudia Yoana Carmona-González, and Claudia Patricia FlórezRamos. 2015. "Estimation of leaf area in coffee leaves (Coffea arabica L.) of the Castillo® variety." Bragantia AHEAD.

Wahyuningsih, S. 2012. Prospek Batuan Fosfat Sebagai Penyedia Hara P Di Lahan Hutan Tanaman Industri (Hti) Bergatra Tanah Ultisol.

Wachjar, Ade, Yadi Setiadi, and Lies Wahyuni Mardhikanto. 2002. "Pengaruh Pupuk Organik dan Intensitas Naungan terhadap Pertumbuhan Bibit Kopi Robusta (Coffee canephora Pierre ex Froehner)." Jurnal Agronomi Indonesia.

30.1 . 